\title{
State Corroding Federalism
}

\author{
Hongbin Cai ${ }^{\mathrm{a}} \quad$ Daniel Treisman ${ }^{\mathrm{b}}$
}

\section{October 2002}

\begin{abstract}
Competition among regional or local governments in a decentralized political system is often thought to discipline lazy or corrupt officials, improving public good provision and increasing welfare. Some scholars note possible distortions due to spillovers or a "race-to-the-bottom", but suggest that central transfers or regulations can remedy these. Both arguments take for granted a framework of constitutional order in which the central government can collect taxes, allocate transfers, and enforce regulations effectively. We show that if central enforcement capacity is considered endogenous, interjurisdictional competition may itself erode the central government's capacity to channel such competition in welfare-enhancing directions. Under certain conditions, regional governments compete to attract capital by sheltering firms from central tax collectors, bankruptcy courts, or regulators. The result at equilibrium is weaker central law enforcement and usually lower welfare: interjurisdictional competition corrodes the state. We illustrate with three examples-from Russia, China, and the US - of cases in which such competition apparently encouraged subnational politicians to help businesses evade central taxes or regulations.
\end{abstract}

Published in Journal of Public Economics, March 2004, 88, pp.819-43.

JEL Codes: H1, H3, H7, P5

Keywords: capital mobility, decentralization, federalism, interjurisdictional competition, corruption.

${ }^{\text {a }}$ Department of Economics, University of California, Los Angeles.

${ }^{b}$ Department of Political Science, University of California, Los Angeles, 4289 Bunche Hall, Los Angeles CA 90095-1472 (corresponding author). 


\section{Introduction}

Since Tiebout's classic essay (1956), a literature has developed that emphasizes the benefits of political decentralization and the competition among regional or local governments that it makes possible. Competition for mobile residents should match bundles of public goods to residents' demands more accurately (Oates 1972). Competition for mobile capital should improve governance by increasing the cost to officials who provide public services inefficiently or steal budget funds (Brennan and Buchanan 1980). Competition may also reduce governments' incentives to distort resource allocation, for instance by bailing out failing enterprises (Qian and Roland 1998). ${ }^{1}$

A newer literature argues, by contrast, that subnational competition may also introduce certain distortions. Competition for capital may be "too" intense, leading to a "race-to-the-bottom" in local tax rates, welfare provision, or the supply of consumer-oriented local public goods like parks or libraries (Keen and Marchand 1997). Or it may prompt local governments to exploit spillovers, exporting taxes or pollution to their neighbors (Gordon 1983, Oates and Schwab 1988). The overwhelming consensus has been that such problems can be solved by central government intervention (Cumberland 1981, Gordon 1983, Rivlin 1992, Wildasin 1989). If interregional competition leads to excessive pollution or underprovision of public goods with externalities, the central government can impose regulations and minimum standards or provide the public goods itself. If tax competition depletes regional government revenues, the central government can collect and share taxes on mobile bases, or allocate corrective grants to the "losers" from such interregional capital mobility. ${ }^{2}$

In this paper, we challenge this sanguine view, at least in its application to developing countries. We argue that the central government's ability to correct distortions introduced by

\footnotetext{
${ }^{1}$ Decentralization may also avoid noted inefficiencies of centralized decision-making. Central officials may often lack detailed information about local tastes (Hayek 1939). Decision-making by a centralized legislature may permit a narrow majority of regions to expropriate the others, or generate norms of reciprocity that result in overspending (Besley and Coate 2000; Weingast 1979). A central government's ability to insure regions against exogenous shocks, increasing welfare, will create moral hazard for the regions (Persson and Tabellini 1996).

${ }^{2}$ For useful reviews and discussions of these literatures, see Oates (1999), Inman and Rubinfeld (1997), Wilson (1999) and McKinnon and Nechyba (1997).
} 
interregional competition should be considered endogenous. Interregional competition for capital may not just erode the resources and limit the options of regional governments: it may encourage actions by them that weaken constitutional order and corrode the capacities of the central state to regulate and collect taxes. The problem is not just a "race-to-the-bottom" but a race to escape-or defraud-the top. In countries from China to Russia and Argentina, increased interregional competition for capital in recent decades has coincided with a fall in central government revenues, high or increasing tax evasion, and increased political conflict—overt or covert-over the distribution of revenues and regulatory authority. ${ }^{3}$

Previous literature on tax competition-even the part that focused on the distortions-made one key assumption: a framework of constitutional order in which the central government's ability to set its tax rates, collect taxes, and enforce regulations was taken for granted. In some contextsmunicipal finance in the U.S., for instance-this is a largely innocuous assumption. However, in many countries where decentralization is a live political issue-even the US on occasion-central law enforcement is imperfect and constitutional arrangements are open to question. ${ }^{4}$

We argue in this paper that interjurisdictional competition will itself sometimes erode the law enforcement and effective tax collection that are necessary in order for central government to correct its excesses. Building more infrastructure and spending tax revenues prudently are not the only ways that subnational governments can compete to attract capital. Another way is to promise to protect firms from the need to pay central taxes in full or to observe central regulations. Subnational governments reduce costs for businesses operating in their jurisdiction by deliberately undermining central policies and capacity. Such subnational protection occurs in many guises, some illegal, some legal, others of unclear status. A mayor may lobby or pressure central tax collectors to look the other

\footnotetext{
3 There are, of course, many reasons for these trends; however, conflict between central and provincial governments over tax revenues and regulatory authority is important in all three countries and has coincided with an opening up of the economy to external and interregional capital flows.

4 Blanchard and Shleifer (2000) emphasize the importance of centralized enforcement, and argue that this explains differences in performance in China and Russia.
} 
way when they audit a certain firm; a state governor may throw obstacles in the way of central regulatory agents. If regional courts rule first on such matters, they may impede or at least delay resolution in the central government's favor. While such activities may be rare in developed countries, we believe they are extremely common in developing and even middle income countries.

We develop a model in which subnational governments can engage in such fiscal or regulatory protection and in which the central government's enforcement role is endogenous. ${ }^{5}$ We show that decentralization and competition for capital will, under certain conditions, reduce tax revenues, increase regulatory violations, reduce central government spending on law enforcement, and reduce welfare. Subnational governments will invest less in infrastructure when they can compete for capital by offering protection, and sometimes even less than under centralization. At the same time, subnational protection helps firms evade taxes, reducing the central tax take, which leads to lower central government investment in law enforcement (and, though we do not model this explicitly, would reduce funds available for allocating corrective grants). Lower investment in infrastructure and law enforcement worsen the business environment, reducing output. Thus, decentralization and capital mobility can erode the capacity of the central government to enforce the law and lead to diversion of resources into unproductive evasion and protection. Central regulations or corrective subsidies are not a solution since at equilibrium subnational governments impede enforcement of such regulations and support tax evasion that reduces the central government's ability to finance such subsidies.

We do not claim that decentralization is always bad, only that it can have real costs for which no simple remedies exist. Competition between jurisdictions can be efficiency-enhancing or efficiency-depleting. It can take place within the framework of stable institutions, or it can help to undermine existing institutions. We use the model to define under what conditions the costs of decentralization and capital mobility are likely to outweigh the benefits. Finally, we present three examples — from Russia, China, and the US — of cases in which we believe competition for capital

\footnotetext{
5 A vast literature has emerged on endogenous enforcement, since at least Becker (1968). On endogenous honesty and effort of tax collectors, see for instance Besley and McLaren (1993).
} 
increased incentives for subnational politicians to help businesses evade central taxes or regulations.

The danger that local governments may be "captured" by business interests is well known. ${ }^{6}$ To our knowledge, however, no one has pointed out that interjurisdictional competition will often increase the incentive for local officials to be captured. And business interests may capture such officials even without paying any bribes. That regional governments may seek to impose externalities on each other and may compete down their tax rates or public spending are also familiar results. ${ }^{7}$ But that regional governments will illicitly force down the actual tax revenues of the central government is not widely recognized. ${ }^{8}$ Federal arrangements have been praised for, in some circumstances, "preserving markets" (Weingast 1995). But since markets require a framework of law-and-order that central state actors help to provide, the benefits of interjurisdictional competition must be balanced against the incentives they provide to corrode such centrally-supplied order.

\section{The Model and Preliminary Analysis}

To illustrate our main points clearly, we present a simple model using specific functional forms and making simplifying assumptions about parameter values. In most places it is not difficult to see that the qualitative results of the model continue to hold in more general environments. In fact, we have derived all the main results in a model with general functional forms (available upon request).

\subsection{The Model}

A country consists of two non-overlapping regions, 1 and 2, each governed by a regional government,

\footnotetext{
${ }^{6}$ See, for instance, Bardhan and Mookherjee (2000).

${ }^{7}$ See, for instance, Edwards and Keen (1996), McKinnon and Nechyba (1997), Oates and Schwab (1988).

${ }^{8}$ Several papers do consider vertical competition between governments at different levels. Keen (1997) and Keen and Kotsogiannis (1999) consider how horizontal competition between regions interacts with the central government's tax setting. However, since they do not model regional government protection of local capital, they reach different results. Salmon (1987) and Breton (1996) argue that under vertical competition between governments that provide the same public good or service, the performance of each government serves as a yardstick which voters can use to evaluate performance of the others.
} 
$\mathrm{G}_{\mathrm{i}}$. The whole country is governed by a central government, C. In each of the two regions, a large number of identical enterprises produce a single good. ${ }^{9}$ This good serves as the numeraire throughout the model. For our purposes, it is easy to think of the aggregate production function of region $i=1,2$ as $f\left(k_{i}, I_{i}, L\right)$, where $k_{i}$ is the capital flowing to region $i, I_{i}$ is infrastructure investment in region $i$ made by its government, and $L$ represents some national public goods provided by the central government. We will call $L$ investment in law-and-order, although clearly many other interpretations are possible. The production function is assumed to take the Cobb-Douglas form of $f_{i}\left(k_{i}, I_{i}, L\right)=A k_{i}^{1-a-b} I_{i}^{a} L^{b}$, where $A>0, a>0, b>0,1-a-b>0$. There is a fixed amount of capital in the economy, denoted by $2 K$, which is perfectly mobile between regions. ${ }^{10}$ Perfect mobility of capital implies that the net marginal productivity of capital should be equal across regions.

The central government levies a revenue (sales) tax on enterprises. ${ }^{11}$ We assume that enterprises try to evade tax, at a certain risk. Specifically, if the official tax rate is $t$, an enterprise pays an effective tax rate of $(1-h) t$, where $h$ is the proportion of revenue the enterprise hides. Sometimes $h$ will be referred to as the enterprise's level of tax evasion. Given $h$, the probability of the enterprise being caught evading tax is $p(h)$ and the fine if caught is $\zeta(h)$ of its gross revenue, where both $p(h)$ and $\zeta(h)$ are increasing. For simplicity, we assume that the expected fine as a percentage of the enterprise's gross revenue, $p(h) \zeta(h)$, takes the form of $0.5 \beta h^{2}$, where $\beta$ represents how potentially costly tax evasion is. By the law of large numbers, the government will get $0.5 \beta h^{2}$ of the total revenue in the economy from fines collected on enterprises. For expositional ease, we define $T=(1-h) t+0.5 \beta h^{2}$ as the "real" tax rate.

\footnotetext{
${ }^{9}$ The model can be extended such that regional governments provide local public goods to (immobile) residents.

${ }^{10}$ All that is strictly needed is that capital is less mobile across countries than across regions within the country.

11 This assumption simplifies analysis compared to the alternative- a tax on returns to capital. Moreover, it seems to fit better the reality of transition and developing countries, where sales taxes are often favored because they are easier than others to collect.
} 
In response to enterprises' tax evasion, the central government can spend resources to improve tax collection. However, regional governments $G_{1}$ and $G_{2}$ can also spend resources to help enterprises in their regions evade federal taxes. (While we develop the model in terms of tax evasion, a similar logic would apply to evasion of costly central regulations.) Specifically, we suppose that in region $i$, the tax evasion cost parameter is $\beta\left(z, g_{i}\right)=\rho e^{-\delta g_{i}} \ln (z+\theta)$, where $\rho>0, \delta \geq 0$ and $\theta>0$ are parameters, $z \in[0,1]$ is the central government's tax collection effort (e.g., auditing) and $g_{i} \in[0,1]$ is the regional government $\mathrm{G}_{\mathrm{i}}$ 's protection effort, both normalized as shares of gross revenue. The reason we normalize government auditing (and local government protection) to total firm revenue is that-for a given rate of evasion - the probability of getting caught will depend on the amount of central auditing (and of local protection) relative to the number of firms and their scale of operations. Note that $\partial \beta / \partial z \geq 0, \quad \partial \beta / \partial g_{i}<0$ and $\partial^{2} \beta / \partial g_{i}^{2} \geq 0$. Furthermore, we have $\partial^{2} \beta / \partial z \partial g_{i} \leq 0$ for $i=1,2$, meaning that regional governments' protection reduces the marginal effectiveness of the central government's tax collection effort. For convenience, denote $\beta_{0}=\beta(0,0)=\rho \ln \theta$. One interpretation of $\beta_{0}$ is that it represents the "normal" level of tax collection. Strictly positive $z$ then means that the central government is using extra resources to improve tax collection.

Governments, in our model, are assumed to be partially self-interested: they care about some combination of social welfare and their own consumption. ${ }^{12}$ This general formulation embraces both the extreme Leviathan and the purely benevolent social planner, along with everything in between. Specifically, the governments' objective functions consist of (1) resources available for private consumption, and (2) their utility from corruptly consuming fiscal revenues. The first erm, total private consumption, will also be our social welfare function. ${ }^{13}$ The second term is represented by $\lambda \ln c_{i}$, where $c_{i}$ is government $\mathrm{G}_{\mathrm{i}}$ 's consumption from money corruptly stolen (the central

\footnotetext{
${ }^{12}$ For a similar approach, see Edwards and Keen (1996).

${ }^{13}$ We assume that citizens derive utility from law-and-order only insofar as it increases output and consumption.
} 
government's corrupt consumption is denoted $c_{0}$ ), and $\lambda$ is the governments' corruption propensity. When $\lambda=0$, the governments are honest and maximize social welfare. If $\lambda$ approaches infinity, then governments are totally corrupt and care only about their own consumption.

We consider two standard government structures: centralization and decentralization. Under centralization, all decisions are made by the central government; the local governments $G_{1}$ and $G_{2}$ merely take orders and implement policies. Under decentralization, $\mathrm{G}_{1}$ and $\mathrm{G}_{2}$ have their own budgets at their discretion that can be allocated among infrastructure investment, $I_{i}$, corrupt consumption, $c_{i}$ and protection, $g_{i}$. The central government decides the official tax rate $t$, tax collection effort $z$, and law and order $L$. Note that for simplicity, we assume that governments choose tax collection effort and protection on a per firm (adjusted for size) basis. Let the total output in region $i$ be $f\left(k_{i}, I_{i}, L\right)$;

then $\mathrm{G}_{\mathrm{i}}$ spends $g_{i} f\left(k, I_{i}, L\right)$ on protection and $\mathrm{C}$ spends $z \sum_{i=1,2} f\left(k_{i}, I_{i}, L\right)$ on tax collection. How the governments share the fiscal revenue will be specified later.

The timeframe of the game is such that the governments make policy choices first and then entrepreneurs decide on tax evasion and allocate capital across regions to maximize the net returns on capital. The focus will be on how governments $\left(C, G_{1}, G_{2}\right)$ strategically make policy decisions under centralization and decentralization. The solution concept is Subgame Perfect Equilibrium (SPE), which requires that all the parties have rational expectations about future events and make optimal choices (given other players' choices) at each point in time. From now on, equilibrium means SPE.

\subsection{Tax Evasion and Effective Tax Rate}

Consider enterprises' tax evasion. Given an official tax rate of $t$ and tax evasion cost parameter $\beta$ (determined by tax collection effort $z$ of the central government and protection effort $g_{i}$ of regional government $\mathrm{G}_{\mathrm{i}}$ ), enterprises in region $i$ will choose tax evasion $h_{i}$ to maximize 


$$
\pi_{i}=1-T_{i}=1-\left(1-h_{i}\right) t-0.5 \beta\left(z, g_{i}\right) h_{i}^{2}
$$

where $\pi_{i}$ is the proportion of revenue that enterprises in region $i$ can keep. The solution to this simple maximization problem is $h_{i}=t / \beta$. Thus, enterprises will engage in more tax evasion if tax evasion is less costly (lower $\beta$ ), or if the official tax rate $t$ is higher. With the optimal tax evasion, enterprises' net proportional revenue is

$$
\pi_{i}=1-T_{i}=1-t+0.5 t^{2} / \beta\left(z, g_{i}\right)
$$

The real tax rate is then given by

$$
T_{i}=t-0.5 t^{2} / \beta\left(z, g_{i}\right)
$$

For fixed $z$ and $g_{\mathrm{i}}$, the above expression gives a Laffer curve of the effective tax rate. That is, $T_{i}$ initially increases in the official tax rate $t$; but beyond a certain level, it becomes decreasing in $t$. The official tax rate $t$ that maximizes the real tax rate of (2.2) is $\hat{t}=\beta$, leading to the maximal real tax rate

$$
\hat{T_{i}}=0.5 \beta\left(z, g_{i}\right)
$$

In this case enterprises' net revenue proportion is

$$
\hat{\pi}_{i}=1-\hat{T}_{i}=1-0.5 \beta\left(z, g_{i}\right)
$$

We assume that $\rho \ln (1+\theta) \leq 1$ so that $\hat{t}$ is always less than one; the maximal real tax rate $\hat{T}$ is therefore less than 50 percent.

\section{Results}

\subsection{Equilibrium under centralization}

Under centralization, the central government makes all the policy decisions. Specifically, it chooses the tax rate $t$, tax collection spending $z$, infrastructure investments $I_{1}$ and $I_{2}$, law-and-order 
investment $L$, protection $g_{1}$ and $g_{2}$, and corrupt consumption for regional governments $c_{1}$ and $c_{2}$ and for itself $c_{0}$ to maximize

$$
\Pi=\pi_{1} f\left(k_{1}, I_{1}, L\right)+\pi_{2} f\left(k_{2}, I_{2}, L\right)+\lambda\left(\ln c_{1}+\ln c_{2}+\ln c_{0}\right)
$$

where $\pi_{i}$ is given by (2.1). Note that it is assumed in (2.1) that governments do not observe tax evasion and hence have to respect the enterprises' incentive constraint; i.e., enterprises in region $i$ will choose evasion effort $h_{i}=t / \beta$. The first two terms of (3.1) are total private consumption in the economy, which also serves as the social welfare criterion. The last term is the sum of all government corruption utilities. There are two reasons the regional governments' corrupt consumption enters into the central government's utility function. First, under centralization, the regional governments are mere agents of the central government, and the amount of administrative corruption that the center tolerates can be viewed as an indirect payment to the agents. Second, this formulation of the central government's utility function makes comparisons between centralization and decentralization more meaningful. If regional governments' corrupt consumption did not feature in the central government's objective function, then centralization would automatically lead to lower corruption simply because we would have assumed away the ability of two of the governments to be corrupt. Note, however, this feature is not critical to the main results of the model.

The aggregate government budget constraint is

$$
\sum_{i=1,2}\left[I_{i}+c_{i}+g_{i} f\left(k_{i}, I_{i}, L\right)\right]+z \sum_{i=1,2} f\left(k_{i}, I_{i}, L\right)+L+c_{0}=\sum_{i=1,2} T_{i} f\left(k_{i}, I_{i}, L\right)
$$

The left hand side is total government expenditure, with the first term being local government expenditure and the subsequent terms being central government expenditure. The right hand side is total government revenue. The budget constraint can be rewritten as

$$
\sum_{i=1,2}\left(I_{i}+c_{i}\right)+L+c_{0}=\sum_{i=1,2}\left(T_{i}-z-g_{i}\right) f\left(k_{i}, I_{i}, L\right)
$$


The central government maximizes its objective function (3.1) subject to the aggregate government budget constraint (3.2). Clearly, we should have $g_{1}=g_{2}=0$ since protection merely wastes resources. By the symmetry of the model and concavity of the objective function, the optimal solution must also be symmetric: $I_{1}=I_{2}=I$, and $c_{1}=c_{2}=c_{0}=c$. Consequently the capital allocation will be symmetric as well: $k_{1}=k_{2}=K$. Let us denote the centralization solution by $\left(I^{c}, L^{c}, z^{c}, t^{c}, c^{c}, \mu^{c}\right)$, where $\mu$ is the shadow price (opportunity cost) of fiscal revenue and the superscript "c" stands for centralization. This solution is characterized by the following proposition. All proofs are in the appendix.

Proposition 1 Under centralization, the central government's optimal policies are

(i) when $\beta_{0} \geq H(a, b, A, \lambda, K)$,

$$
\begin{gathered}
\mu=1, \quad z=0, \quad t=\tilde{t}, \quad \pi=1-0.5 \beta_{0}, \quad c=\lambda \\
I=A^{\frac{1}{1-a-b}} a^{\frac{1-b}{1-a-b}}(2 b)^{\frac{b}{1-a-b}} K, \quad L=A^{\frac{1}{1-a-b}} a^{\frac{a}{1-a-b}}(2 b)^{\frac{1-a}{1-a-b}} K
\end{gathered}
$$

(ii) when $\beta_{0}<H(a, b, A, \lambda, K)$,

$$
\begin{gathered}
\mu=\tilde{\mu}>1, \quad z=\frac{\rho}{2}\left(1-\frac{1}{\tilde{\mu}}\right)-\theta>0, \quad t=\beta(z, 0), \\
\pi=1-\frac{\rho}{2}\left[\ln \frac{\rho}{2}+\ln \left(1-\frac{1}{\tilde{\mu}}\right)\right], \quad c=\lambda / \tilde{\mu}, \\
I=(A \omega)^{\frac{1}{1-a-b}} a^{\frac{1-b}{1-a-b}}(2 b)^{\frac{b}{1-a-b}} K, \quad L=(A \omega)^{\frac{1}{1-a-b}} a^{\frac{a}{1-a-b}}(2 b)^{\frac{1-a}{1-a-b}} K
\end{gathered}
$$

where $\omega=1-z-\left(1-\frac{1}{\tilde{\mu}}\right) \pi$, and $H(a, b, A, \lambda, K), \tilde{t}$ and $\tilde{\mu}$ are defined in the Appendix.

To understand Proposition 1 , note that $\beta_{0} \geq H(a, b, A, \lambda, K)$ holds when $\beta_{0}, A$, and $K$ are relatively large and $\lambda$ is relatively small. So the condition requires that tax collectability is sufficiently 
high at the normal level of tax collection, the economy is sufficiently productive, and the governments are not too corrupt. As a result, government's optimal spending needs can be met with available tax revenue. Under this condition, equilibrium spending on law-and-order and infrastructure should both have a marginal product of 1 , the opportunity cost of fiscal revenue. On the other hand, when $\beta_{0}<H(a, b, A, \lambda, K)$, tax collection at the normal level will not satisfy the spending needs of the governments. Thus the opportunity cost of fiscal revenue will be greater than one, and the government will spend additional resources on auditing. The government's optimal spending on lawand-order and infrastructure will be lower, reflecting the higher opportunity cost of fiscal revenue.

Proposition $2 z^{c}, t^{c}, c^{c}$, and $\mu^{c}$ are increasing in $\lambda$, while $I^{c}$ and $L^{c}$ are decreasing in $\lambda$.

The intuition for Proposition 2 is simple. When the central government cares more about corrupt consumption, it will increase such consumption while cutting spending on infrastructure and law-and-order. Moreover, to finance higher corrupt consumption it needs to increase tax collection effort and the tax rate to raise more revenue. When $\lambda=0$, the central government maximizes social welfare, and hence the centralization solution at $\lambda=0$ is the socially optimal solution. The result below immediately follows from Proposition 2.

Corollary 1 Under centralization, so long as the central government is not entirely benevolent (i.e., $\lambda>0$ ) it under-invests in infrastructure and law-and-order but over-invests in tax collection and sets a tax rate higher than is socially optimal.

\subsection{Equilibrium under decentralization}

Under decentralization, the central and regional governments share fiscal revenue and responsibilities. On the expenditure side, we suppose the central government spends its revenue on law-and-order, $L$, 
tax collection, $z$, and corrupt consumption, $c_{0}$, while each local government $\mathrm{G}_{1}$ spends its tax revenue on infrastructure, $I_{i}$, corrupt consumption, $c_{i}$, and protection, $g_{i}$. On the revenue side, we suppose that the central and regional governments bargain over a linear sharing rule dividing tax revenues between them, and that the share for each region is the same. Specifically, let $R_{i}$ be the tax revenue collected in region $i$, then $\mathrm{C}$ gets $\gamma R_{i}-B_{i}$ and $\mathrm{G}_{\mathrm{i}}$ gets $(1-\gamma) R_{i}+B_{i}$, where $\gamma \in[0,1]$ is the share of $\mathrm{C}$ and $B_{i}$ is the lump sum transfer to $\mathrm{G}_{\mathrm{i}}$.

We study the following game. At stage 0 , the central and regional governments bargain over a fiscal revenue sharing rule. At stage 1, the three governments make their policy choices simultaneously. C chooses a sales tax rate $t$ for the whole economy, and a fiscal revenue allocation $\left(c_{0}, L, z\right) . \mathrm{G}_{\mathrm{i}}$ sets $\left(I_{i}, c_{i}, g_{i}\right)$. At stage 2 , enterprises choose tax evasion and allocate capital across the regions. If returns to capital are the same across regions, each region gets half of the total capital.

We solve the game with backward induction. Capital mobility implies that

$$
\pi_{1} \partial f\left(k_{1}, I_{1}, L\right) / \partial k_{1}=\pi_{2} \partial f\left(k_{2}, I_{2}, L\right) / \partial k_{2}
$$

Since $k_{1}+k_{2}=2 K$, we can solve for the capital allocation from (3.3), which is given by

$$
k_{i}=2 K \frac{I_{i}^{\frac{a}{a+b}} \pi_{i}^{\frac{1}{a+b}}}{I_{i}^{\frac{a}{a+b}} \pi_{i}^{\frac{1}{a+b}}+I_{j}^{\frac{a}{a+b}} \pi_{j}^{\frac{1}{a+b}}}
$$

Clearly $\partial k_{i} / \partial I_{i}>0, \partial k_{i} / \partial \pi_{i}>0, \partial k_{i} / \partial I_{j}<0$ and $\partial k_{i} / \partial \pi_{j}<0$, where $i \neq j \in\{1,2\}$. That is, capital inflow into one region increases in the region's protection and infrastructure investment, and decreases in the other region's protection and infrastructure investment. It can be readily checked that in the symmetric case when $I_{1}=I_{2}=I$ and $\pi_{1}=\pi_{2}=\pi$,

$$
\frac{\partial k_{i}}{\partial I_{i}}=\frac{a}{2(a+b)} \frac{K}{I}, \quad \frac{\partial k_{i}}{\partial \pi_{i}}=\frac{1}{2(a+b)} \frac{K}{\pi}
$$


At stage 1 , the $\mathrm{G}_{\mathrm{i}}$ 's choose $\left(I_{i}, g_{i}, c_{i}\right)$ to maximize $\Pi_{i}=\pi_{i} f\left(k_{i}, I_{i}, L\right)+\lambda \ln c_{i}$ subject to the budget constraint $I_{i}+c_{i}=\left[(1-\gamma) T_{i}-g_{i}\right] f\left(k_{i}, I_{i}, L\right)+B_{i}$. The central government chooses $\left(t, z, L, c_{0}\right)$ to maximize $\Pi=\pi_{1} f\left(k_{1}, I_{1}, L\right)+\pi_{2} f\left(k_{2}, I_{2}, L\right)+\lambda \ln c_{0} \quad$ subject to the budget constraint $L+c_{0}=\sum_{i=1,2}\left[\left(\gamma T_{i}-z\right) f\left(k_{i}, I_{i}, L\right)-B_{i}\right]$. We focus on the equilibrium that is symmetric between the two regions: $g_{1}=g_{2}, I_{1}=I_{2}$, and $c_{1}=c_{2}$. It follows that $k_{1}=k_{2}=0.5 \mathrm{~K}$.

The equilibrium outcome in stage 1 clearly depends on the budget-sharing rule. With rational expectations, the governments bargain over a fiscal revenue sharing scheme to maximize their joint surplus. What is important for our result is that the fiscal revenue sharing scheme will be chosen such that the opportunity cost of fiscal revenue is equalized across governments.

As before, we focus on the symmetric equilibrium of the game, which we denote by $\left(I^{d}, L^{d}, z^{d}, g^{d}, t^{d}, c^{d}, \mu^{d}\right)$, where the superscript "d" stands for decentralization. The solution is characterized in the proof of Proposition 3 of the Appendix, where for technical tractability, we suppose $\gamma=0.5$.

The properties of equilibrium under decentralization depend on two crucial factors-the intensity of interregional competition for capital $(a+b)$, and the effectiveness of regional protection at blocking the central government's tax collection efforts $(\delta)$. Three cases are of interest.

First, if competition for capital is relatively intense $(a+b$ close enough to zero) and protection is sufficiently effective ( $\delta$ large enough), then under decentralization regional governments will use protection to attract mobile capital. They will substitute non-growth-promoting instruments (protection) for growth-promoting ones (infrastructure investment), resulting in lower infrastructure investment than under centralization. In response, the central government will reduce its tax collection effort, since it is less effective. The regions' lower investment in infrastructure will also cause the central government to cut law-and-order spending, since the two investments are complementary. These effects reinforce one another, leading to lower aggregate output as well as lower government 
rents than under centralization. Social welfare will also be lower. The danger of decentralization is captured in Proposition 3. ${ }^{14}$

Proposition 3 Suppose competition for capital is sufficiently intense ( $a+b$ close enough to zero) and protection is sufficiently effective at obstructing central tax collection ( $\delta$ large enough). Then in equilibrium under decentralization: (i) $g^{d}>0=g^{c}$; (ii) $I^{d} \leq I^{c}, L^{d} \leq L^{c}, c^{d} \leq c^{c}$, and $z^{d} \leq z^{c}$. Social welfare is lower under decentralization than under centralization.

Of course, if competition for capital is intense but regional governments' efforts to protect local firms are not effective, governments will instead seek to attract capital by investing in infrastructure. This is the standard result in the literature to date. ${ }^{15}$ Larger infrastructure investments by the regional governments will in turn induce the central government to invest more in law-andorder and tax collection. Note that decentralization under capital mobility cannot produce greater total government surplus than centralization, since the total government surplus is maximized under centralization. Thus, from the point of view of the governments, investment levels are too high under decentralization. Proposition 4 captures the welfare-enhancing potential of decentralization.

\footnotetext{
${ }^{14}$ Note that the superiority of centralization under these conditions-relatively intense competition for capital and sufficiently effective protection-does not depend on assuming a benevolent central government. In fact we have assumed partially self-interested central government, and we hold government objectives constant throughout the comparison.

${ }^{15}$ See, e.g., Qian and Roland (1998). Besides pointing out how regional protection can reverse the welfare effects of decentralization, our paper differs from Qian and Roland (1998) in several ways. First, in our model tax revenue is endogenous, which implies that higher investments in infrastructure and law-and-order will increase fiscal revenue and hence fiscal expenditure. In contrast, Qian and Roland assume that the total tax revenue is fixed and hence higher infrastructure implies lower public good provision. Second, governments do not maximize social welfare in our model, but also care about their own consumption. As a consequence, growth-enhancing investments in infrastructure and law-and-order are always under-provided relative to the socially optimal levels. Third, Qian and Roland focus on questions different from ours - in particular, the incentive for governments to bail out failing firms. Our main concern is to model decentralization when law enforcement and tax collection are endogenous.
} 
Proposition 4 Suppose competion for capital is intense $(a+b$ close enough to zero $)$ and protection is relatively ineffective $\left(\delta\right.$ small). Then in equilibrium under decentralization: (i) $g^{d}=g^{c}=0$; (ii) $I^{d} \geq I^{c}, L^{d} \geq L^{c}$, and $z^{d} \geq z^{c}$. Social welfare is greater than under centralization.

Finally, if competition for capital is insufficiently intense $(a+b$ close to 1$)$, then decentralization will induce neither protection nor additional infrastructure investment. In fact, both infrastructure and law-and-order investments will be lower under decentralization than under centralization. This results from a simple free-rider problem: since the central government and the regional governments share the total fiscal revenue, each of them only gets a proportion of the marginal revenue generated by its investments. Consequently, social welfare is likely to be lower under decentralization than under centralization.

In sum, the model shows that intense capital competition can either increase or decrease welfare, depending on whether the policy instruments of regional governments that are effective in attracting capital are also welfare-enhancing. In the examples discussed below, we show that this is more than just a theoretical point. In a number of observed cases, regional governments do appear to seek to attract capital by offering protection rather than investing in infrastructure.

\subsection{Discussion}

Several simplifying assumptions deserve comment. First, we model a system of tax sharing, in which the central government sets the tax rate and collects the revenue, rather than allowing for local taxes and collection agencies. This fits the reality of several important developing countries (Russia, China before 1994), and closely approximates others (e.g. Mexico, Indonesia) where almost all subnational revenues come from central tax shares and transfers. ${ }^{16}$

\footnotetext{
${ }^{16}$ In the 1990s, Mexico's subnational governments collected only about 5 percent of their total revenues, while in Indonesia the figure was about 7 percent.
} 
Would the results change if locally-collected taxes were included? It seems likely that the logic we identify would also apply—and perhaps more strongly. Consider several possibilities. First, suppose that in addition to the central tax rate, $t, \mathrm{G}_{\mathrm{i}}$ levies a local tax at rate $t_{i}$ without any enforcement problem (no evasion of local taxes) on a separate tax base (say a poll tax on immobile residents). In this case, the only effect of the local tax would be to relax the local governments' budget constraint by the amount of revenue collected locally. So long as competition for capital is intense and protection is effective, local governments will still have an incentive to compete (through protection and/or infrastructure investment) to attract capital. Second, suppose that both central and regional governments set tax rates, $t$ and $t_{i}$ respectively, on the same base as before, sales. The first order effect would be for regions to want to protect more than before. In the model without local taxes, G's protection both increases the amount of capital-and hence sales-in region $i$ and reduces the effective tax rate, $T$, and hence $\mathrm{G}_{\mathrm{i}}$ 's real tax rate, $\left(1-\right.$ ?)T. $\mathrm{G}_{\mathrm{i}}$ trades off these two effects. If $\mathrm{G}_{\mathrm{i}}$ had its own tax on sales, its total real tax rate would be $t_{i}+(1-$ ?)T, which is less sensitive to the effect of protection on $T$. Thus, the incentive to protect would probably be stronger. ${ }^{17}$ In the case of complete tax separation and no tax sharing, the local governments get no benefit from central tax revenue and hence will have the maximum incentive to protect.

In analyzing decentralization, we assumed that the governments bargained over a linear fiscal revenue sharing rule that maximized their total surplus. Linear rules are assumed for tractability, and moreover fit many actual cases (in which proportional tax sharing is combined with lump sum transfers). The assumption of efficient bargaining in stage 0 (i.e., maximizing total government surplus) facilitates the comparison of the centralization and decentralization solutions, but is not crucial. It ensures that the shadow price (opportunity cost) of fiscal revenue is equalized across governments, so we can compare centralization to decentralization with the same objective function

\footnotetext{
17 There are various second order effects which might complicate the result. Horizontal tax-rate competition between regions might restrict both regions to low rates (the "race-to-the-bottom"); vertical competition between regional and central governments could lead them to set the aggregate tax rate "too high" on the far side of the Laffer curve. For an analysis of these effects, see Keen (1997).
} 
and budget constraints. Otherwise, under an arbitrarily chosen tax division rule, there might be additional distortions under decentralization, ncreasing the likelihood that decentralization is worse than centralization under the conditions of Proposition 3.

To make the fairest comparison between centralization and decentralization, we assumed that governments at both levels have the same propensity for corruption. One consequence of this is that even though under centralization the tax rates are too high relative to the first best (Corollary 1), local governments' protection of firms from central taxation is not likely to be welfare-enhancing because the local governments are equally corrupt and protection wastes resources. Of course, if central officials are much more corrupt than their local counterparts, decentralization-and local government protection - will be welfare-enhancing. This may certainly be the case in some settings.

\section{Three Examples}

When regional governments can help enterprises evade central taxes or regulations effectively, we showed that decentralization-and the competition for capital it stimulates-may reduce welfare. In such cases, the regional governments waste resources on protection, and the central government underinvests in law-and-order. For such effects to be large, three conditions are relevant:

(A) returns to capital must not decrease too fast (competition is intense),

(B) regional government protection must be relatively effective at helping firms evade central taxes or regulations, and thus at attracting capital to a region.

(C) marginal infrastructure investments must be relatively ineffective at attracting capital.

(A) will tend to be true in regions (or countries) that are relatively undeveloped, in which labor is plentiful, or which have large natural resources (that require capital to exploit). (B) will tend to be true in countries in which central regulatory and law enforcement bureaucracies are weak or corrupt or in those in which constitutional decentralization gives regional governments significant powers. For instance, a great deal of administrative delegation may make central enforcement harder. (C) will tend 
to be true in countries where, for exogenous reasons, some regions are initially much more attractive to investors than others. This could be because of geographical location, threshold effects in infrastructure investment, or other factors.

Below, we describe three cases_-from Russia, China, and the US — that meet some or all of these conditions. Proving that regional protection has actually occurred in a given setting is always difficult, for obvious reasons: governments prefer to leave few traces of such activity. However, in each of the following cases, we believe that welfare-reducing regional protection did occur.

\subsection{Tatarstan and Tatneft}

In the mid-1990s, Russia experienced an epidemic of tax non-payments. Many of the country's largest—and previously most profitable-companies claimed that they could not pay their tax liabilities. One leader among these was Russia's fifth largest oil company, Tatneft, which was based in the ethnic republic of Tatarstan on the Volga River. ${ }^{18}$

In October 1996, the Russian federal government threatened to bankrupt the company unless it quickly paid off its $\$ 75$ million federal tax arrears (Bekker 1996). Tatneft had managed to amass these arrears despite earning pre-tax profits the previous year of $\$ 467.9$ million (Henderson 1996). The company's main protector, Tatarstan's president Mintimer Shaimiev, quickly struck back, accusing the central government of Soviet tactics and announcing he would ignore any federal order to close the company (Moscow Times 1996). Shaimiev's good relations with local courts would have made it hard to get a bankruptcy order enforced. Days later, Shaimiev traveled to Moscow and got prime minister Chernomyrdin to lower the estimates of Tatneft's tax debt (Jamestown Foundation 1996). But Tatneft was soon accumulating federal arrears again, prompting the government to cut the company's access to an export pipeline. Shaimiev flew to Moscow to meet with the new prime minister, Sergei

\footnotetext{
${ }^{18}$ Russia in general - and Tatarstan in particular - in the 1990s fit the conditions listed for protection to occur: abundant labor; natural resources; weak and corrupt central enforcement agencies along with considerable administrative decentralization. Difficulties of intraregional transportation also reduce the marginal effectiveness of investments in infrastructure within one region for attracting capital.
} 
Kiriyenko, and was soon able to announce that: "The question of access to pipe lines has now been taken off the agenda." (Moscow Times 1998).

Shaimiev's vigorous efforts to prevent enforcement of tax laws against Tatneft coincided with a flood of foreign investment into the company. In December 1996, just months after the company was threatened with bankruptcy, Tatneft was the second Russian firm to float ADRs on the London Stock Exchange (RFE/RL Newsline 1996). Its share price soared by more than three times during 1997. In March 1998, it also placed ADRs on the New York Stock Exchange. Western banks provided the company with multimillion dollar loans. Tatneft's close ties to the Tatarstan government seem to have attracted foreign investors. According to one Western business columnist, the dramatic rise in Tatneft's share price "was achieved in no small part due to the full faith and support with which the Tatarstan government blessed its top enterprise. State officials went out of their way to participate in the company's road show and give assurances to investors" (Peach 1997). On its website, the company boasted under the heading "strategy" that it intended to "continue to maintain a close relationship with the Tatarstan government" and would "seek to participate in the development of a new tax regime". 19

By investing resources in co-opting local courts and in trips to Moscow to pressure federal officials, the Tatar president helped enterprises such as Tatneft reduce their tax costs. This helped to attract a large inflow of foreign investment. Had Shaimiev been less assertive in defending "his" companies, their profitability would have been lower, and the stock market speculators—both Russian and Western—would have looked to other Russian or emerging market companies. Oil and gas firms based in other Russian regions were simultaneous ly seeking foreign loans and investors. Competition for such capital gave added urgency to regional leaders' efforts to collude with local businesses.

\footnotetext{
${ }^{19}$ See www.tatneftjsc.ru/finstate/maint.htm
} 


\subsection{Smuggling on China's South Coast}

During the last two decades, China's coastal regions have become centers of small-scale industry, fueling the country's economic development. Special economic zones, offering favorable tax regimes for foreign investors, have acted as a catalyst. By the mid-1990s, the number of such zones had grown to more than 1,000. Net foreign direct investment in China reached $\$ 37$ billion in $1997 .{ }^{20}$

Competition among provinces, townships, cities, and zones to attract the flow of foreign capital is intense. In an influential article, Montinola, Qian and Weingast (1996) argued that provincial and local governments compete to attract this capital in two generally welfare-enhancing ways-by improving local laws, regulations, and taxes that affect businesses; and by offering better infrastructure and access to markets. We argue that there is an additional way-local and provincial governments attract investors by helping them evade central government customs duties on imports.

Since foreign trade liberalization, smuggling has grown dramatically. In the late 1990s, an estimated $\$ 12$ billion was lost each year in unpaid tariffs. Smuggling has been concentrated in the regions where the competition for foreign capital was strongest. A glimpse into this phenomenon was offered by the affair of the Hong Kong-based Yuanhua Group, a firm run by a former native of Fujian province, Lai Changxing. Assisted by much of the Fujian provincial and Xiamen city administrations, Lai smuggled goods worth more than $\$ 6$ billion into Fujian in the 1990s (Lawrence 2000).

Clearly, the corrupt local bureaucrats who protected Yuanhua had motives that went beyond the desire to attract foreign investment. Lai courted them with lavish bribes and visits to his personal brothel. Nevertheless, their support for smuggling helped to attract foreign investment to the region in two significant ways. First, Lai made large local investments himself. He bought another city's soccer

\footnotetext{
${ }^{20}$ Henley, Kirkpatrick, and Wilde (1998). China also meets some of the conditions for significant levels of protection: abundant labor, weak enforcement and regulatory bureaucracies, although one might perhaps expect infrastructure investments within the coastal provinces to be more effective at attracting investment than in Russia. Even here, though, incentives for provincial governments to invest in infrastructure are reduced by several factors. The initial levels of infrastructure were quite low (especially in Fujian and Guangdong because of their historical role as potential battle fronts with the Taiwan government) so large amount of investments might be required to generate positive effects.
} 
team and moved it to Xiamen, built a 30-story hotel, a cinema and entertainment complex, and was planning to build an 88-floor office block. Second, among the goods smuggled in were raw materials such as rubber and plastics, which were in great demand from the region's many Taiwan-funded shoe and umbrella factories. Lai also smuggled oil into the province-at one point as much as one sixth of all crude oil on the Chinese market, by unofficial reports (Lawrence 2000). He sold this oil at half the official price; after the central government cracked down on Lai, local gasoline prices rose by nearly 50 cents. Local officials must have been acutely aware that such cheap raw materials played a vital role in keeping the local economy competitive and attractive to foreign investors. Between 1990 and 1996, the province managed to increase its share of the annual inflow of foreign direct investment from 9.3 to 13.0 percent of the nationwide total (Henley, Kirkpatrick, and Wilde 1998).

That Lai-and, presumably, many other smugglers_-were able to continue massive operations for years owed much to the protection of a network of local and provincial officials, as well as local agents of central bureaucracies. We do not have evidence that provincial officials lobbied the central party organs not to investigate corruption in Fujian, although it is likely that they did. Once the central government did send a task force of investigators, however, they were watched and impeded by local officials. Local state security operatives with ties to the city's vice mayor reportedly tapped the central task force's phones and the Xiamen city deputy police chief alerted Lai of his impending arrest, enabling him to escape abroad (Hajari 2000). Interregional competition strengthened the incentive for local officials to try to attract mobile capital by protecting smugglers, who either invested in the local economy themselves or helped to reduce local raw materials prices, thus encouraging investment by others.

\subsection{Mountaintop removal mining in West Virginia}

One way a regional government can reduce the cost of doing business in its jurisdiction is by failing to enforce-or impeding the enforcement of-central regulations. In West Virginia, coal mining 
accounts for 13 percent of the state's gross product and a third of its business tax revenues (Vollers 1999). The governor in the late 1990s, Cecil Underwood, received large campaign contributions from coal companies. At the same time, in accordance with the ethos of American federalism, state agencies were delegated responsibility to enforce key provisions of federal regulatory legislation. ${ }^{21}$

The profitability of coal mining in West Virginia is increased by a technique known as mountaintop removal, in which the mining companies "blast off entire hilltops to uncover valuable, low-sulfur coal reserves" (Ward 1999a). Trucks and bulldozers then dump leftover rock and earth into neighboring valleys. Mining operations in the state would be far less attractive to investors if such techniques were restricted. However, there are large potential environmental costs if acid runoff pollutes rivers and if mountaintop removal leads to deforestation or flooding (Vollers 1999).

The 1977 federal Surface Mining Control and Reclamation Act (SMCRA) provides detailed regulations designed to alleviate the environmental impact of coal mining. Implementing regulations prohibit mining operations within 100 feet of active streams unless it can be shown that this will not damage the streams (Vollers 1999). West Virginia's Department of Environmental Protection, a state agency, was delegated the task of enforcing this act, overseen by the federal Office of Surface Mining.

In July 1998, a group of private individuals and environmental groups sued the DEP for allegedly not enforcing SMCRA. And in October 1999, a Republican federal judge, Charles Haden II, agreed, charging that the dumping of waste in "valley fills", as routinely occurred in local mountaintop removal mining, violated the federal regulation banning activity within 100 feet of streams (Haden 1999). In effect, the West Virginia DEP had not been enforcing this federal regulation for years. Haden ordered the DEP to stop issuing permits to coal companies that proposed to dump waste into streams. According to one DEP official, this would have ruled out 59 of 62 applications then pending.

\footnotetext{
${ }^{21}$ Thus, although very different from the developing economies of Russia and China, West Virginia does meet many of the conditions under which one would expect protection to occur: abundant labor (unemployment of 7.9 percent as of January 1999), natural resources, considerable delegation of enforcement responsibilities to state agencies. Because of its location somewhat far from major metropolitan areas, it also seems unlikely that a marginal dollar invested in infrastructure would have a big impact on business investment.
} 
It also hamstrung the state's attempt to attract and retain capital. The Arch Coal company, whose operations in West Virginia had been disrupted, purchased a giant strip mine in Wyoming, and began dismantling equipment in West Virginia to ship to Wyoming. ${ }^{22}$ West Virginia lost 900 coal industry jobs in 1998-99, most of which moved to Wyoming (Vollers 1999). When Judge Haden ordered the halt on new permits, the local school board president claimed this would cost the county \$6 million in taxes (Ward 1999a).

The state government quickly struck back, hiring an outside law firm to fight the environmentalists' lawsuit. The two main lawyers billed the state $\$ 106,000$ for their first two months of work (Ward 1999b, 1999c). At the same time, in-house DEP lawyers were seconded to work on the case. Other DEP officials were diverted from their usual business to draft assessments of the cost of halting such mining. The result was apparently quite effective. In late October, Haden lifted his order, despite his belief that opposition was based on "misunderstandings and, at worst, egregious misrepresentations." He blamed a "a firestorm of reaction" from "defendants and state government officials" for creating a "shrill atmosphere of discord" (Ward 1999a).

Note that this is not a case of environmental spillovers. It is a case in which the fear of losing mobile capital motivated a state government to invest in helping local firms circumvent costly federal regulations. Such actions are inefficient because resources are dissipated in the attempt to prevent a transfer of capital from one location to another. If the federal legislation is socially inefficient, then circumventing it might increase welfare. But an externality distorts state level decisionmaking in this sort of case. The cost of activities to attract capital-mounting legal challenges to protect local companies, tolerating environmental degradation—are weighed against the benefit of capital attracted. But capital attracted from one state to another leaves the first worse off in ways that are not internalized. This is precisely the sort of case in which central regulation is needed to avoid the

\footnotetext{
${ }^{22}$ It is hard to imagine a more vivid piece of evidence of the interstate mobility of capital than this crating up of equipment from one mine to ship to another when the regulatory regime seemed to be changing. The West Virginia political leadership was directly responding to a valid fear that capital would flow out of the local coal industry if environmental enforcement increased.
} 
socially inefficient outcome. However, regional governments' efforts to block enforcement of such federal regulations render such interventions unreliable. ${ }^{23}$

\section{Conclusion}

Under certain conditions, decentralization and the interjurisdictional competition it stimulates can have large desirable effects. The need to attract capital may render local officials more honest and efficient, and prompt them to invest more in infrastructure. However, in other conditions, decentralization can have serious negative consequences, eroding the institutional foundations that make competition work to the benefit of all. If federalism—or more generally, decentralization—can sometimes preserve markets, at other times it may help to corrode the central state and with it the benefits of economic integration and legal order.

Most previous models assumed that local governments compete to attract capital in growthpromoting ways, for instance by investing in infrastructure or providing public goods cost-effectively.

We showed that if competition for capital is intense, businesses are hard to attract with infrastructure, and central bureaucracies are weak or have devolved enforcement powers to lower-level governments, then local officials may instead compete by offering firms covert protection against central taxes and regulations. ${ }^{24}$ In response, central government will reduce central tax collection effort and investment in law-and-order. If the central government is much more predatory than local governments, this could increase welfare. But if both level governments are equally benevolent or predatory, welfare would be higher under complete centralization.

\footnotetext{
${ }^{23}$ Are such cases rare? In the US, most major federal environmental legislation delegates enforcement authority to state agencies. The National Wildlife Federation recently released a report claiming that 38 of 50 states were failing to enforce a provision of the Clean Water Act limiting water pollution caused by runoffs from forests and farms. The federal agency that oversees Medicaid recently claimed that more than 12 states were falsely inflating their Medicaid costs to earn higher federal matching funds (Nugent 2000). Other reports of poor state enforcement of federal regulations surface often enough to suggest that they are at least quite widespread.

${ }^{24}$ Another way regional governments can compete to attract businesses is by offering to protect the managerswho make locational decisions_-against their own shareholders. Bebchuk and Ferrell (1999) argue that interstate competition has led to US state laws on mergers and takeovers that favor management over shareholders.
} 
Various questions remain for future work. Like most of the models that find advantages in decentralization, ours is static; additional insights might emerge from an examination of this logic in a dynamic setting. The assumptions of homogeneous regions and symmetry might also be relaxed. If regions are heterogeneous, there are likely to be multiple equilibria even in a single-stage game.

\section{Appendix}

Proof of Proposition 1: With zero protection, and under symmetry, the aggregate budget constraint becomes $2 I+L+3 c=2(T-z) f(K, I, L)$. Then the Lagrange for the central government's maximization problem is

$$
2 \pi f(k, I, L)+3 \lambda \ln c+\mu[2(1-\pi-z) f(K, I, L)-2 I-L-3 c]
$$

where $\mu \geq 0$ is the Lagrange multiplier, and $\pi_{i}=1-T_{i}=1-t+0.5 t^{2} / \beta\left(z, g_{i}\right)$. The first order conditions are

$$
\begin{array}{ll}
\text { w.r.t } t: & (1-\mu) \partial \pi / \partial t=0 \\
\text { w.r.t } z: & (1-\mu) \partial \pi / \partial z-\mu=0 \\
\text { w.r.t } c: & \lambda / c-\mu=0 \\
\text { w.r.t } I: & {[(1-\mu) \pi+\mu(1-z)] \partial f / \partial I-\mu=0} \\
\text { w.r.t } \mathrm{L}: & 2[(1-\mu) \pi+\mu(1-z)] \partial f / \partial L-\mu=0
\end{array}
$$

From these conditions, we easily get $c=\lambda / \mu$ and

$$
I=(A \omega)^{\frac{1}{1-a-b}} a^{\frac{1-b}{1-a-b}}(2 b)^{\frac{b}{1-a-b}} K, \quad L=(A \omega)^{\frac{1}{1-a-b}} a^{\frac{a}{1-a-b}}(2 b)^{\frac{1-a}{1-a-b}} K
$$

where $\omega=1-z-\left(1-\frac{1}{\mu}\right) \pi$. Thus, $f=A^{\frac{1}{1-a-b}} \omega^{\frac{a+b}{1-a-b}} a^{\frac{a}{1-a-b}}(2 b)^{\frac{b}{1-a-b}} K$.

From the first order condition with respect to $t$, we have either $\mu=1$ or $\partial \pi / \partial t=0$. First consider the case of $\mu=1$. Then the partial derivative of the Lagrange with respect to $z$ is -1 , so it 
must be that $z=0$. Hence $\omega=1$. The official tax rate can be recovered from the budget constraint, $2\left[t-\frac{0.5 t^{2}}{\beta_{0}}\right] f=2 I+L+3 \lambda$, which can be rewritten as

$$
2\left[t-\frac{0.5 t^{2}}{\beta_{0}}\right]=2 a+2 b+3 \lambda A^{\frac{-1}{1-a-b}} a^{\frac{-a}{1-a-b}}(2 b)^{\frac{-b}{1-a-b}} K^{-1}=H(a, b, A, \lambda, K)
$$

Clearly $H$ is increasing in $\lambda$ and decreasing in $K$ and $A$. Since the maximum value of the real tax rate on the left hand side is $\hat{T}=0.5 \beta_{0}$, the above equation can be satisfied for some $\tilde{t}$ if $\beta_{0} \geq H(a, b, A, \lambda, K)$. If this is the case, we have found the centralization solution.

If $\beta_{0}<H(a, b, A, \lambda, K)$, then the solution must have $\partial \pi / \partial t=0$ and $\mu>1$ (since $\left.\partial^{2} \pi / \partial t^{2}>0\right)$. From $\partial \pi / \partial t=0$, we have $\hat{t}=\beta(z, 0)$, thus $T=0.5 \beta(z, 0)$ and $\pi=1-0.5 \beta(z, 0)$.

From the first order condition with respect to $z$, we get

$$
z=\frac{\rho}{2}\left(1-\frac{1}{\mu}\right)-\theta
$$

Thus,

$$
T=0.5 \beta(z, 0)=\frac{\rho}{2}\left[\ln \frac{\rho}{2}+\ln \left(1-\frac{1}{\mu}\right)\right]
$$

Let $\tau=1-\frac{1}{\mu}$. From the budget constraint, $2(T-z) f(K, I, L)=2 I+L+3 c$, we get

$$
\rho\left(\ln \frac{\rho \tau}{2}-\tau\right)+\theta=\omega\left[2 a+2 b+3 \lambda(1-\tau)(A \omega)^{\frac{-1}{1-a-b}} a^{\frac{-a}{1-a-b}}(2 b)^{\frac{-b}{1-a-b}} K^{-1}\right]
$$

where $\omega=1-z-\left(1-\frac{1}{\mu}\right) \pi=1+\theta-\tau-\frac{\rho \tau}{2}\left[1-\ln \frac{\rho \tau}{2}\right]$. Solving for $\tau$ from the above equation, we then can get the solution $\tilde{\mu}$ and hence all other variables. 
Proof of Proposition 2: Let $\bar{\lambda}$ be the solution to $\beta_{0}=H(a, b, A, \lambda, K)$. For all $\lambda \leq \bar{\lambda}$, clearly $I^{c}, L^{c}, z^{c}$, and $\mu^{c}$ are independent of $\lambda, t^{c}$ and $c^{c}$ are increasing in $\lambda$. For $\lambda>\bar{\lambda}$, we want to show that $\mu$, or equivalently $\tau$, is increasing in $\lambda$. First note that

$$
\frac{\partial \omega}{\partial \tau}=-1-\frac{\rho}{2}\left[1-\ln \frac{\rho \tau}{2}\right]+\frac{\rho}{2}=-\left[1-\frac{\rho}{2} \ln \frac{\rho \tau}{2}\right]=-\pi<0
$$

Rewriting the equation from which we solved for $\tau$, we have

$$
3 \lambda(1-\tau) A^{\frac{-1}{1-a-b}} \omega^{\frac{-a-b}{1-a-b}} a^{\frac{-a}{1-a-b}}(2 b)^{\frac{-b}{1-a-b}} K^{-1}=\rho\left(\ln \frac{\rho \tau}{2}-\tau\right)+\theta-2 \omega(2 a+b)
$$

It is easy to check that the first term on the right hand side is increasing in $\tau$, hence the right hand side is increasing in $\tau$. Furthermore, when $\tau$ is small, the right hand side is smaller than the left hand side. Therefore, it must be that $\tau$ (and hence $\mu$ ) is increasing in $\lambda$ (see Milgrom and Roberts, 1994). It follows that $\omega$ is decreasing in $\lambda$. Since $I^{c}$ and $L^{c}$ are increasing in $\omega$, they are decreasing in $\lambda$. Since $t^{c}$ and $\mathrm{z}^{c}$ are increasing in $\tau$, they are increasing in $\lambda$. For $c^{c}$, since the marginal utility of $c$ is increasing in $\lambda$, clearly $c^{c}$ will be increasing in $\lambda$ (see Milgrom and Shannon, 1994). $\quad$ Q.E.D

Proof of Proposition 3: For technical tractability, we suppose $\gamma=0.5$. Our qualitative result should still hold for other values of $\gamma$.

The first order conditions for $\mathrm{G}_{\mathrm{i}}$ 's optimization problem are

$$
\begin{array}{lll}
\text { w.r.t } & c_{i}: & \lambda / c_{i}-\mu_{i}=0 \\
\text { w.r.t } & I_{i}: & {\left[1-T_{i}+0.5 \mu_{i} T_{i}-\mu_{i} g_{i}\right]\left[\frac{\partial f}{\partial I_{i}}+\frac{\partial f}{\partial k_{i}} \frac{\partial k_{i}}{\partial I_{i}}\right]-\mu_{i}=0} \\
\text { w.r.t } \mathrm{g}_{\mathrm{i}}: & {\left[\left(0.5 \mu_{i}-1\right) \frac{\partial T_{i}}{\partial g_{i}}-\mu_{i}\right] f+\left[1-T_{i}+0.5 \mu_{i} T_{i}-\mu_{i} g_{i}\right] \frac{\partial f}{\partial k_{i}} \frac{\partial k_{i}}{\partial \pi_{i}} \frac{\partial \pi_{i}}{\partial g_{i}}=0}
\end{array}
$$

where $\mu_{i}$ is the Lagrange multiplier representing the opportunity cost of fiscal revenue to G. In a symmetric equilibrium, we have $I_{1}=I_{2}=I, c_{1}=c_{2}=c, g_{1}=g_{2}=g$, and $k_{1}=k_{2}=K$. 
Under symmetry, the first order conditions for C's optimization problem are

$$
\begin{array}{lll}
\text { w.r.t } t: & \left(0.5 \mu_{0}-1\right) \partial T / \partial t=0 \\
\text { w.r.t } z: & \left(0.5 \mu_{0}-1\right) \partial T / \partial z-\mu_{0}=0 \\
\text { w.r.t } c_{0}: & \lambda / c_{0}-\mu_{0}=0 \\
\text { w.r.t } \mathrm{L}: & 2\left[1-T+0.5 \mu_{0} T-\mu_{0} z\right] \partial f / \partial L-\mu_{0}=0
\end{array}
$$

where $\mu_{0}$ is the Lagrange multiplier representing the opportunity cost of fiscal revenue to $\mathrm{C}$.

In stage 0 , the central and regional governments will bargain to a revenue sharing rule that maximizes the total surplus of the governments. This implies that $\mu_{1}=\mu_{2}=\mu_{0}=\mu$; that is, the opportunity cost of fiscal revenue to any government must be the same. This is easy to understand. Since the fiscal sharing rule is to maximize the total surplus for the governments in stage 0 , one dollar of tax revenue should generate the same marginal value no matter which government it is spent on. Otherwise, moving fiscal revenue from a lower opportunity cost source to a higher one would increase total government utility. That in equilibrium the marginal value of fiscal revenue is equalized across governments implies that ex post the governments will not renegotiate budget allocations with intergovernmental transfers even when such transfers are feasible. Because of the intergovernmental transfers, the meaningful budget constraint is the aggregate government budget constraint (3.2).

The first order conditions define the best response of each government against the others' strategies. Clearly, $c=c_{0}=\lambda / \mu$. Combining these conditions and using (3.4), we get

$$
\begin{array}{ll}
\text { w.r.t } t: & (0.5 \mu-1) \partial T / \partial t=0 \\
\text { w.r.t } z: & (0.5 \mu-1) \partial T / \partial z-\mu=0 \\
\text { w.r.t } \mathrm{L}: & 2[1-T+0.5 \mu T-\mu z] \partial f / \partial L-\mu=0 \\
\text { w.r.t } I: & \frac{1+a+b}{2(a+b)}[1-T+0.5 \mu T-\mu g] \frac{\partial f}{\partial I}-\mu=0 \\
\text { w.r.t } \mathrm{g}: \quad & {\left[(1-T+0.5 \mu T-\mu g) \frac{1-a-b}{2(a+b)(1-T)}-0.5 \mu+1\right] \frac{\partial \pi}{\partial g}-\mu=0}
\end{array}
$$

Coupled with the aggregate government budget constraint, these conditions define the decentralization solution. 
As in Proposition 1, from the first order condition with respect to $t$, we have either $\mu=2$ or $\partial T / \partial t=0$. Note that the first order conditions with respect to $z$ and $g$ are independent of $\mathrm{I}$ and $\mathrm{L}$, hence $z$ and $g$ can be solved from these two equations in terms of $\mu$ and $t$. In the case of $\mu=2$, clearly $z=0$. From (2.1), the first order condition with respect to $g$ can be simplified as

$$
(0.5-g) \frac{t-T}{1-T}=\frac{1}{\delta} \frac{2(a+b)}{1-a-b}
$$

Clearly, when $\delta$ is sufficiently large and $a+b$ is sufficiently smaller than one, the right hand side is smaller than the left hand side at $g=0$. As $g$ increases, the left hand side will eventually become smaller than the right hand side. Therefore, there exists a solution $g^{d}>0$ to the equation. Conversely, when $\delta$ is sufficiently small or $a+b$ is close to one, there will be no solution to the equation and hence $g^{d}=0$. Under the conditions that $\delta$ is sufficiently large and $a+b$ is sufficiently close to one, the first order conditions with respect to I and L become

$$
\begin{aligned}
& A b K^{1-a-b} I^{a} L^{b-1}=1 \\
& \frac{1+a+b}{2(a+b)}(0.5-g) A a K^{1-a-b} I^{a-1} L^{b}=1
\end{aligned}
$$

Solving for I and L yields

$$
\begin{gathered}
I=A^{\frac{1}{1-a-b}} a^{\frac{1-b}{1-a-b}}(2 b)^{\frac{b}{1-a-b}} K\left[\frac{1+a+b}{2(a+b)}(0.5-g) 0.5^{\frac{b}{1-b}}\right]^{\frac{1-\mathrm{b}}{1-\mathrm{a}-\mathrm{b}}} \\
L=A^{\frac{1}{1-a-b}} a^{\frac{a}{1-a-b}}(2 b)^{\frac{1-a}{1-a-b}} K\left[\frac{1+a+b}{2(a+b)}(0.5-g) 0.5^{\frac{1-a}{a}} \frac{\mathrm{a}}{]^{1-\mathrm{a}-\mathrm{b}}}\right.
\end{gathered}
$$

Therefore,

$$
f=A^{\frac{1}{1-a-b}} a^{\frac{a}{1-a-b}}(2 b)^{\frac{b}{1-a-b}} K\left[\frac{1+a+b}{2(a+b)}(0.5-g)\right]^{\frac{\mathrm{a}}{1-\mathrm{a}-\mathrm{b}}} 0.5^{\frac{\mathrm{b}}{1-\mathrm{a}-\mathrm{b}}}
$$

From (A1),

$$
(0.5-g) \frac{1-a-b}{2(a+b)}=\frac{1}{\delta} \frac{1-T}{t-T}
$$


When $\delta$ is sufficiently large, the right hand side will be sufficiently small. Thus $(0.5-g) \frac{1+a+b}{2(a+b)}$ will be smaller than one. It follows that in the case of $\mu=2$, under the specified conditions, (i) $g^{d}>0=g^{c}$; (ii) $I^{d} \leq I^{c}, L^{d} \leq L^{c}, c^{d} \leq c^{c}$, and $z^{d}=z^{c}=0$, where the centralization solution is evaluated at the smallest possible $\mu^{c}=1$. Since total output is smaller under decentralization than under centralization, and the governments waste resources on protection under decentralization, clearly the social welfare is smaller under decentralization than under centralization.

Now consider the case of $\partial \pi / \partial t=0$ and $\mu>2$. From $\partial \pi / \partial t=0$, we have $t=\beta(z, g)$, thus $T=0.5 \beta(z, g)$ and $\pi=1-0.5 \beta(z, g)$. From the first order condition with respect to $z$, we get

$$
z=\frac{\rho e^{-\delta g}}{2}\left(0.5-\frac{1}{\mu}\right)-\theta
$$

From the first order condition with respect to $g$, we get

$$
\left(\frac{1}{\mu}-g\right) \frac{1-a-b}{2(a+b)}+\left(0.5-\frac{1}{\mu}\right)\left(T \frac{1+a+b}{2(a+b)}-1\right)=\frac{1}{\delta}
$$

Again, when $\delta$ is sufficiently large and $a+b$ is sufficiently smaller than one, there exists a solution $g^{d}>0$ to the equation. To see this, note that the left hand side can be arbitrarily big when $g=0$ as long as $a+b$ is sufficiently smaller than one, since $T(z, 0)>0$. On the other hand, the left hand side can be arbitrary small when $g=\frac{1}{\mu}$ as long as $\delta$ is sufficiently large, since $T \rightarrow 0$ as $\delta \rightarrow 0$. Similar to the argument for the case of $\mu=2$, by comparing the first order conditions with respect to $\mathrm{I}$ and $\mathrm{L}$ under centralization and under decentralization, one can show that $I^{d} \leq I^{c}, L^{d} \leq L^{c}$ and hence $f^{d}<f^{c}$ for the same $\mu$. And because for the same $\mu, g^{d}>0=g^{c}$ and $z^{d}<z^{c}$, it must be that $T^{d}<T^{c}$. This implies that the opportunity cost of fiscal revenue $\mu$ must be higher under decentralization than under centralization, which further reduces $I^{d}, L^{d}$, and $z^{d}$, relative to the 
centralization solution. Therefore, the proposition holds when $\delta$ is sufficiently large and $a+b$ is sufficiently small.

Q.E.D.

Proof of Proposition 4: From the proof of Proposition 3, it is clear that when $\delta$ is sufficiently small, then $g^{d}=0$. For simplicity, we only consider the case of $\mu=2$. The other case can be proven similarly as before. When $\mu=2$, we have $z=0$, and the first order conditions with respect to I and L become

$$
A b K^{1-a-b} I^{a} L^{b-1}=1, \quad \frac{1+a+b}{4(a+b)} A a K^{1-a-b} I^{a-1} L^{b}=1
$$

Solving for I and L yields

$$
\begin{aligned}
& I=A^{\frac{1}{1-a-b}} a^{\frac{1-b}{1-a-b}}(2 b)^{\frac{b}{1-a-b}} K\left[\frac{1+a+b}{2(a+b)} 0.5^{\frac{1}{1-b}}\right]^{\frac{1-\mathrm{b}}{1-\mathrm{a}-\mathrm{b}}} \\
& L=A^{\frac{1}{1-a-b}} a^{\frac{a}{1-a-b}}(2 b)^{\frac{1-a}{1-a-b}} K\left[\frac{1+a+b}{2(a+b)} 0.5^{\frac{1}{a}}\right]^{\frac{a}{1-a-b}}
\end{aligned}
$$

Therefore, $\quad f=A^{\frac{1}{1-a-b}} a^{\frac{a}{1-a-b}}(2 b)^{\frac{b}{1-a-b}} K\left[\frac{1+a+b}{2(a+b)}\right]^{\frac{\mathrm{a}}{1-\mathrm{a}-\mathrm{b}}} 0.5^{\frac{\mathrm{a}+\mathrm{b}}{1-\mathrm{a}-\mathrm{b}}}$

Clearly, when $a+b$ is sufficiently small, $I^{d} \geq I^{c}, L^{d} \geq L^{c}$ and hence $f^{d} \geq f^{c}$. Q.E.D. 


\section{References}

Bardhan, Prahab and Dilip Mookherjee. 2000. "Capture and Governance at Local and National Levels," American Economic Review, 90, 2, May, pp.135-9.

Bebchuk, Lucian and Allen Ferrell, "Federalism and Corporate Law: The Race to Protect Managers from Takeovers," Columbia Law Review, 99, 5, June, pp.1168-99.

Becker, Gary. 1968. "Crime and Punishment: An Economic Approach,” Journal of Political Economy, 76, March/April, pp.169-217.

Bekker, Aleksandr. 1996. "Dunning Letter Sent to Biggest Budget Debtors," Segodnya, October 16, p.1, translated in Current Digest of the Post-Soviet Press, 1996, Vol. 48, No.42, p.17.

Besley, Timothy and Stephen Coate. 2000. "Centralized versus Decentralized Provision of Local Public Goods: A Political Economy Analysis,” London School of Economics, manuscript.

Besley, Timothy and John McLaren. 1993. "Taxes and Bribery: The Role of Wage Incentives," Economic Journal, 103, January, 119-41.

Blanchard, Olivier and Andrei Shleifer. 2000. "Federalism With and Without Political Centralization: China versus Russia," NBER Working Paper, 7616.

Brennan, Geoffrey and James M. Buchanan. 1980. The Power to Tax: Analytical Foundations of a Fiscal Constitution, New York: Cambridge University Press.

Breton, Albert. 1996. Competitive Governments: An Economic Theory of Politics and Public Finance, New York: Cambridge University Press.

Cumberland, John H. 1981. "Efficiency and Equity in Interregional Environmental Management," Review of Regional Studies, 2, pp.1-9.

Edwards, Jeremy and Michael Keen. 1996. "Tax Competition and Leviathan,” European Economic Review, 40, pp.113-34.

Gordon, Roger H. 1983. "An Optimal Taxation Approach to Fiscal Federalism," Quarterly Journal of Economics, 98, 4, pp.567-86.

Haden, Charles. 1999. "Memorandum Opinion and Order", Civil Action No.2:98-0636, US District Court, Charleston Division, at www.osmre.gov.

Hajari, Nisid. 2000. "Fall of an Empire: A high-level smuggling scandal lays bare the corruption that is plaguing the People's Republic," Time Asia, Vol.155, No.5, 7 February.

Hayek, Friedrich von. 1948. "The Economic Conditions of Interstate Federalism," in Individualism and Economic Order, Chicago: University of Chicago Press.

Henderson, Peter. 1996. “Tatar Oil Firm Bucks Downward Trend,” Moscow Times, 31 July. 
Henley, John, Colin Kirkpatrick, Georgina Wilde. 1998. "Foreign Direct Investment in China: Recent Trends and Current Policy Issues," working paper, University of Manchester: Institute for Development Policy and Management.

Inman, Robert P. and Daniel L. Rubinfeld. 1997. "The Political Economy of Federalism," in Dennis C. Mueller, ed., Perspectives on Pubilc Choice Theory, New York: Cambridge University Press.

Jamestown Foundation. 1996. Monitor, 31 October.

Keen, Michael. 1997. "Vertical Tax Externalities in the Theory of Fiscal Federalism," WP/97/173, Washington DC: IMF, manuscript.

Keen, Michael and Christos Kotsogiannis. 1999. "Federalism and Tax Competition," Washington, DC: IMF, manuscript.

Keen, Michael and Maurice Marchand. 1997. "Fiscal Competition and the Pattern of Public Spending," Journal of Public Economics, 66, pp.33-53.

Lawrence, Susan. 2000. "China: A City Ruled by Crime," Far Eastern Economic Review, November 30 .

McKinnon, Ronald and Thomas Nechyba. 1997. "Competition in Federal Systems: Political and Financial Constraints," in John Ferejohn and Barry R. Weingast, eds., The New Federalism: Can the States be Trusted?, Stanford: Hoover Institution Press.

Milgrom,Paul and John Roberts. 1994. "Comparing Equilibria," American Economic Review, 84, pp. 441-459.

Milgrom, Paul and Christina Shannon. 1994. "Monotone Comparative Statics," Econometrica, 62, pp. 157-180.

Montinola, Gabriella, Yingyi Qian, and Barry R. Weingast. 1996. "Federalism, Chinese Style: The Political Basis for Economic Success," World Politics, 48, 1, pp.50-81.

The Moscow Times. 1996. “Tatarstan Leader Slams Tax Crusade,” 25 October.

The Moscow Times. 1998. "Tatneft to Resume Oil Exports After Recent Cut,” 9 July.

Nugent, John D. 2000. "State Implementation of Federal Policy as a Political Safeguard of Federalism," Connecticut College: manuscript.

Oates, Wallace E. 1972. Fisal Federalism, New York: Harcourt Brace Jovanovich.

----------. 1999. “An Essay on Fiscal Federalism,” Journal of Economic Literature, September, 37, 3, pp.1120-49.

Oates, Wallace E. and Robert M. Schwab. 1988. "Economic Competition Among Jurisdictions: Efficiency Enhancing or Distortion Inducing," Journal of Public Economics, 35, pp.333-54.

Peach, Gary. 1997. “Tatarstan Pulls Into Lead In Regions' Bid for Cash,” The Moscow Times, 15 July. 
Persson, Torsten and Guido Tabellini. 1996. "Federal Fiscal Constitutions: Risk Sharing and Moral Hazard," Econometrica, 64, 3, pp.623-46.

Qian, Yingyi and Gérard Roland. 1998. "Federalism and the Soft Budget Constraint," American Economic Review, December, 88, 5, pp.1143-62.

RFE/RL Newsline. 1996. 11December.

Rivlin, Alice M. 1992. Reviving the American Dream: The Economy, the States, and the Federal Government, Washington, DC: Brookings Institution Press.

Russian Economic Trends. 1998. 2 July, Russian European Center for Ec onomic Policy.

Salmon, Pierre. 1987. "Decentralization as an Incentive Scheme," Oxford Review of Economic Policy, 3, 2, summer, pp.24-43.

Tiebout, Charles. 1956. "A Pure Theory of Local Expenditures," Journal of Political Economy, 64, October, 416-24.

Vollers, Maryanne. 1999. "Razing Appalachia,” Mother Jones, July/August.

Ward, Ken Jr. 1999a. "DEP to Lift Ban on Strip Mine Permits," Charleston Gazette, Nov 1. April 14. 1999b. "DEP hires outside lawyers to defend it in mining case," Charleston Gazette, .1999c. “City Law Firm Bills DEP Another \$62,000,” Charleston Gazette, June 15.

Weingast, Barry R. 1979. "A Rational Choice Perspective on Congressional Norms," American Journal of Political Science, 23, 245-62.

Weingast, Barry R. 1995. "The Economic Role of Political Institutions: Market-Preserving Federalism and Economic Development," Journal of Law, Economics, and Organization, 11, 1 April, pp.1-31.

Wildasin, David. 1989. "Interjurisdictional Capital Mobility: Fiscal Externality and a Corrective Subsidy," Journal of Urban Economics, 25, pp.193-212.

Wilson, John Douglas. 1999. "Theories of Tax Competition," National Tax Journal, 52, 2, pp.269304. 